\title{
Dry Matter Yield and Nutrient Uptakes of Arabica Coffee Seedlings as Influenced by Lime and Coffee Husk Compost Amendments at Western Ethiopia
}

\author{
Bikila Takala $^{\left.1^{*}\right)}$ \\ ${ }^{1)}$ Ethiopian Institute of Agricultural Research, Jimma Agricultural Research Center, P. O. Box 192, Jimma Ethiopia \\ ${ }^{*}$ Corresponding author: biktak@gmail.com \\ Received: 13 June 2021 / Accepted: 27 July 2021
}

\begin{abstract}
Nursery experiment was conducted at Haru Agricultural Research Sub Center (HARSC) of Jimma Agricultural Research Center, Western Ethiopia, to investigate dry matter yield and its nutrient uptake of Arabica coffee seedlings under different lime and coffee husk compost rates and establish optimum combination of these agricul tural inputs that produce seedlings with better dry matter yield for field planting. The experiment was laid out in a factorial experiment arranged in randomized complete block design with three replications. The treatments included four levels of lime $\left(0,1.6,3.2\right.$ and $\left.4.8 \mathrm{t} \mathrm{ha}^{-1}\right)$ and coffee husk compost $\left(0,5,10\right.$ and $\left.15 \mathrm{t} \mathrm{ha}^{-1}\right)$. Nutrient uptake and dry matter yield data of coffee seedlings were collected and subjected to analysis of variance using SAS package and treatment means were compared at 0.05 probability using Duncan's Multiple Range Test. The results revealed that lime and coffee husk compost rates significantly $(\mathrm{P}<0.01)$ affected NPK uptake and total dry matter yield of coffee seedlings. The highest NPK uptake and total dry matter yield of coffee seedling were obtained from the application of 15 t.ha $^{-1}$ coffee husk compost and combined lime and coffee husk compost at the modest levels of 3.2 t.ha $^{-1}$ lime and 10 t.ha $^{-1}$ coffee husk compost with a nonsignificant variation. From the study, it can be concluded that application of $15 \mathrm{t}^{-h a^{-1}}$ coffee husk compost or combining 10 t.ha $\mathrm{h}^{-1}$ of coffee husk compost and 3.2 t.ha- $\mathrm{h}^{-1}$ of agricultural lime could be a promising alternative amendment for acid soil management and production of vigorous coffee seedlings with high nutrient uptake and high dry matter yield in HARSC areas.
\end{abstract}

Keyword: coffee husk compost, coffee seedling, dry matter, lime, nutrient uptake

\section{INTRODUCTION}

Coffee (Coffea arabica L.), originated in Ethiopia, is the second major traded commodity following to oil (Zelalem, 2013) and thus plays a vital role in the balancing of trade between developed and developing countries. Coffee is an important foreign exchange commodity, contributing in various degrees to the national income of the producing countries (Patricia, 2011). Coffee guarantees a solid basis for promotion of economic development of the producing countries. About 33 million people in 25 African countries derive their livelihoods by growing coffee on their subsistence farms and particularly, in Ethiopia 15 million people directly or indirectly deriving their livelihoods from coffee system (Gray et al., 2013). Ethiopia is the largest producer of coffee in Sub-Saharan Africa and is the fifth largest coffee producer in the world next to Brazil, Vietnam, Colombia and Indonesia, contributing about $7-10 \%$ of total world coffee production (Gray et al., 2013). 
Despite the existence of enormous genetic diversity and importance of the crop in the national economy of the country, its production potential hardly exceeds 0.67 t.ha $^{-1}$ (CSA, 2016). Such a low productivity of the crop mainly stems from drought, inadequate or excessive light or shade, low soil fertility and undulating topography and associated factors, such as soil erosion and soil acidity (IAR, 1996; Yacob et al., 1996; Solomon et al., 2008; Anteneh et al., 2015; Melke \& Ittana, 2015). In addition, coffee cultivation mainly lies on the production of coffee seedlings with desirable characteristics under the recommended nursery management operations. Because any improper handling made at the early stage would remain to cause poor field performances and life span of coffee trees in the field (Anteneh et al., 2015). In this regard, reports (IAR, 1996; Yacob et al., 1996) indicated the use of appropriate potting media from forest soil to produce vigorous and healthy coffee seedlings. However, there is diminished accessibility to the sources, and the accelerated deforestation practices would also call for alternative nursery media preparations from available organic sources with due consideration of both physical and chemical conditions given the well-established cultural practices of using organic material under traditional crop production in Ethiopia (Taye, 1998; Anteneh et al., 2015).

Using compost and animal manures on crops almost always has the desirable effect since they contain substantial amounts of major and trace elements. Furthermore, they have a positive effect on the chemical and physical properties of the soil (Ano \& Ubochi, 2007; Bikila, 2020). Thus, they can be of tremendous benefit in heavily weathered coffee soils because they can improve the soil structure and its water holding capacity (Ano \& Ubochi, 2007; Solomon et al.,2008). The need for renewable, locally available and cheaper options for supplying nutrient to crops is increasingly becoming important because of the need for sustainable agriculture (Ahmad et al., 2006). With growing demands for sustainably produced agricultural produce for environmental, social and food safety reasons, the use and recycling of organic matter is becoming inevitable, particularly for the export market, which depended on commodities such as coffee (Chemura, 2014).

There is thus the need to recognize other potential organic amendment sources such as the by-products from wet and dry coffee processing. The dry method is commonly practiced and easily available at coffee producing areas in West Wollega. These coffee by-products are utilized in other coffee producing countries as soil amendments (Kasongo et al., 2011; Dzung et al., 2013; Kasongo et al., 2013; Nduka et al., 2015). While in Ethiopia enormous quantities are either dumped into streams or burnt in big piles, with contributions to environmental hazards (Solomon, 2006; Gezahegne et al., 2011; Henok \& Tenaw, 2014). Therefore, the objective of this study were to investigate dry matter yield and nutrient uptake of Arabica coffee seedlings under different lime and coffee husk compost rates and establish optimum combination of these agricultural inputs that produce seedlings with better dry matter yield and growth for field planting.

\section{MATERIALS AND METHODS}

\section{Description of the Study Area}

The study was conducted at the Haru Agricultural Research Sub-Center (HARSC) in West Wollega zone, Oromia National Regional State, Western Ethiopia. Haru Agricultural Research Sub-center of the 
Jimma Agricultural Research Center was established in 1998 primarily to address the potentials and constraints in west Wollega specialty coffee growing areas. The center represents the sub-humid tepid to cool mid highlands coffee agro-ecological zone in West Ethiopia. It is found at $28 \mathrm{~km}$ from Gimbi town of West Wollega zone and $466 \mathrm{~km}$ from Addis Ababa in western Ethiopia. The area is geographically located between the latitude of 8'54'30' North and longitude of $35^{\circ} 52^{\prime} 0^{\prime \prime}$ 'East at an elevation of 1750 $\mathrm{m}$. a.s.l. The area is characterized by uni-modal rainfall pattern with an average annual rainfall of $1700 \mathrm{~mm}$. The rainy season starts in March or May and extends up to October. The mean maximum and minimum air temperature is $27.8^{\circ} \mathrm{C}$ and $12.4^{\circ} \mathrm{C}$, respectively. The soil type of the center is Acrisols and sandy clay loam (Zebene \& Wondwosen, 2008; Takala et al., 2020).

\section{Experimental Materials and Procedures}

Fresh coffee husk was collected from the dry coffee processing site in Jitu town, Haru District. The compost was prepared by using $70 \%$ coffee husk, $20 \%$ animal manure and $10 \%$ top soil by volume following the procedure adopted from Solomon (2006). Top soil at a depth of $0-20 \mathrm{~cm}$ was collected from open field which is less fertile and acidic soil to be amended with coffee husk compost and lime (Table 1). Moreover, the different lime rates as powdered lime having a calcium carbonate equivalent of $98 \%$ was used and amount of lime applied at each was calculated on the basis of exchangeable acidity concentration of the soil and crop factor tolerant to soil acidity (Kamprath, 1984).

The lime requirement (LR) was obtained by multiplying exchangeable acidity with soil

Table 1. Selected physico chemical properties of experimental soil and coffee husk compost used for this study

\begin{tabular}{|c|c|c|}
\hline Variable & Top soil & Coffee husk compost \\
\hline Sand (\%) & 64 & - \\
\hline Clay $(\%)$ & 24 & - \\
\hline Silt (\%) & 12 & - \\
\hline Textural class & Sandy clay loam & - \\
\hline Bulk density $\left(\right.$ g.cm $\left.\mathrm{cm}^{3}\right)$ & 1.0 & - \\
\hline $\mathrm{pH}\left(\mathrm{H}_{2} 0\right)$ & 4.72 & 8.5 \\
\hline $\mathrm{pH}(\mathrm{KCl})$ & 3.72 & - \\
\hline Exchangeable acidity $\left(\mathrm{cmol}(+) \mathrm{kg}^{-1}\right)$ & 3.2 & - \\
\hline Organic carbon $(\%)$ & 2.17 & 10 \\
\hline Organic matter $(\%)$ & 3.74 & - \\
\hline Total nitrogen $(\%)$ & 0.19 & 0.86 \\
\hline Total phosphorus (mg.kg-1) & & 187.7 \\
\hline $\mathrm{CEC}\left(\mathrm{cmol}(+) \mathrm{kg}^{-1}\right)$ & 11.35 & 51.2 \\
\hline Available phosphorus (mg. $\left.\mathrm{kg}^{-1}\right)$ & 9.03 & - \\
\hline $\mathrm{Ca}\left(\mathrm{cmol}(+) \cdot \mathrm{kg}^{-1}\right)$ & 2.46 & 12.2 \\
\hline $\mathrm{Mg}\left(\mathrm{cmol}(+) \cdot \mathrm{kg}^{-1}\right)$ & 1.23 & 6.8 \\
\hline $\mathrm{K}\left(\mathrm{cmol}(+) \cdot \mathrm{kg}^{-1}\right)$ & 0.57 & 30.4 \\
\hline $\mathrm{Na}\left(\mathrm{cmol}(+) \cdot \mathrm{kg}^{-1}\right)$ & 0.05 & 1.1 \\
\hline Percent base saturation $(\%)$ & 37.97 & - \\
\hline $\mathrm{C}: \mathrm{N}$ ratio & 11.42 & 11.6 \\
\hline
\end{tabular}


depth $(0.20 \mathrm{~m})$, bulk density and crop factor.

LR, $\mathrm{CaCO}_{3}\left(\mathrm{~kg} \cdot \mathrm{ha}^{-1}\right)=$

(cmol EA $/ \mathrm{kg}$ of soil $* 10000 \mathrm{~m}^{2 *} 0.20 \mathrm{~m} *$

B.D $\left.\left(\mathrm{Mg} / \mathrm{m}^{3}\right) * 1000\right) / 2000 * \mathrm{Cf}$

Where:

$$
\begin{aligned}
\text { EA } & =3.2 \mathrm{cmol} \mathrm{kg}^{-1} \text { of soil } \\
\text { B.D } & 1.0 \mathrm{~g} \mathrm{~cm}^{-3} \\
\mathrm{Cf}(\text { crop factor })= & 1.5 \text { for moderately alu- } \\
& \text { minum tolerant crops. }
\end{aligned}
$$

Accordingly lime rate $(100,66.7,33.3$ and 0$) \%$ of lime requirement obtained from the above equation was used; which is (4.8, $3.2,1.6$ and 0$) \mathrm{t} \mathrm{ha}^{-1}$ respectively.

Menesibu coffee variety was used as test crop. The variety was released in the year 2010 for Wollega specialty coffee producing areas (EIAR, 2015). Coffee seeds were hand harvested from the already established seed orchards at Haru Research Sub Center and prepared as per the standard procedures.

\section{Treatments and Design}

The treatments consisted of four coffee husk compost application rates $(0,5,10$ and 15 t.ha $\left.^{-1}\right)$ and four lime rates $(0,1.6,3.2$, and 4.8 t.ha $\left.^{-1}\right)$ which is $(0,6.25,12.5$ and $18.75 \mathrm{~g})$ and $(0,2,4,6 \mathrm{~g})$ coffee husk compost and lime respectively in $2.5 \mathrm{~kg}$ of acidic soil. The treatments were conducted using polythene bags of $12 \times 22 \mathrm{~cm}$ size. The polythene bags were prepared and firmly filled with the treatment rates which were added and thoroughly mixed with the soil. A 4 x 4 factorial experiment arranged in a randomized complete block design with three replications was used for the study. The so prepared pots were arranged and two coffee seeds were directly sown in polythene bags (potted) at a depth of $1.00 \mathrm{~cm}$. Thinning to one seedling was made in each pot after the emerged seedlings attained a butterfly growth stage and were uniformly managed until they attain desirable stage and end of the study. All other routines pre-and postnursery management practices, including mulching, watering, shading, weeding and other activities were carried out as per the recommendation (IAR, 1996).

\section{Data Collection}

Healthy coffee seedling leaves were collected and prepared from each experimental unit for measurement of dry matter yield and to determine the major plant nutrients $(\mathrm{N}, \mathrm{P}$ and $\mathrm{K}$ ). All plant parts were put separately in labeled paper bag and oven dried at $70^{\circ} \mathrm{C}$ for 24 hours to a constant weight and dry matter measurement $(\mathrm{g})$ was taken separately using sensitive balance. The oven dried leaves were grounded with a stain less steel Wiley mill and digested by a dilute sulfuric-salicylic acid and $30 \%$ hydrogen peroxide; subsequently total nitrogen was determined by the modified-Kjeldahl method (Jackson, 1958); phosphorus by spectrophotometer and potassium by flame photometer (Jackson, 1958). The nutrient uptake was calculated as the product of the nutrient concentration and dry matter yield of coffee seedling as described by Ibiremo and Akanbi (2016). Accordingly the leaf N, P and K -uptake were obtained by multiplying nutrient concentration of respective parameters by leaf dry matter for each treatment.

\section{Statistical Analysis}

The collected soil and plant data were summarized and subjected to ANOVA (analysis of variance) using SAS software (version 9.3) (SAS, 2011). For significantly different treatments, the means were separated using Duncan's Multiple Range Test (DMRT) at $\mathrm{p}=0.05$. 


\section{RESULTS AND DISCUSSION}

\section{Dry Matter Yield}

Analysis of variance showed significant differences due to the main effect of lime $(\mathrm{P}<0.05)$ and compost and interaction effects $(\mathrm{P}<0.01)$ on total dry matter yield. The main effect of compost and its interaction with lime gave highly significant difference $(\mathrm{P}<0.01)$ on shoot to root ratio, unlike the main effect of lime with non-significant variation (Figure 1).

Results showed that application of lime without compost produced a significant increase in total dry matter yield. The magnitude of increment was $14.7-61.8 \%$ for total dry matter over the control with increasing rate (Figure 1). The results indicate that applying lime to the soil might considerably improve the nutrient availability, particularly phosphorus, since it improve soil $\mathrm{pH}$ under which maximum availability of the nutrient may be obtained (Table 3). Similarly, application of compost alone increased total dry matter yield by $61.8-170.6 \%$ over the control with the highest yield from the highest rate (Figure 1).
The highest total dry matter yield (0.92 g.pot $\left.{ }^{-1}\right)$ was obtained from plots received 18.75 g.pot ${ }^{-1}\left(15\right.$ t.ha $\left.^{-1}\right)$ compost without lime and followed by combined application of 3.2 t.ha ${ }^{-1}\left(4\right.$ g.pot $\left.{ }^{-1}\right)$ lime and 10 t.ha $^{-1}\left(12.5\right.$ g.pot $\left.^{-1}\right)$ compost which gave 0.88 g.pot $^{-1}$ for total dry matter. While, the lowest total dry matter $(0.34$ g.pot ${ }^{-1}$ ) was obtained from untreated (control) plot (Figure 1). The increase in total dry matter could be because of decrease in soil acidity which attributed to improved root environment for nutrient availability as well as uptake by coffee seedlings as a result of lime and compost application (Table 1 and 3). This could have been also the reason for poor performance in the control treatment. The result was in line with Anteneh (2015), who reported significant increase in total dry matter yield of coffee seedlings due to lime and $\mathrm{P}$ amendments on acidic soil.

Although the combination effect of lime up to 3.2 t.ha $^{-1}\left(4 \mathrm{~g} \mathrm{pot}^{-1}\right)$ and compost 10 t.ha ${ }^{-1}\left(12.5 \mathrm{~g} \mathrm{pot}^{-1}\right)$ significantly increased the total dry matter yield, increasing lime and compost rate in their combination above the mentioned rate (3.2 t.ha-1 lime and 10 t.ha $^{-1}$ compost) decreased the total dry matter

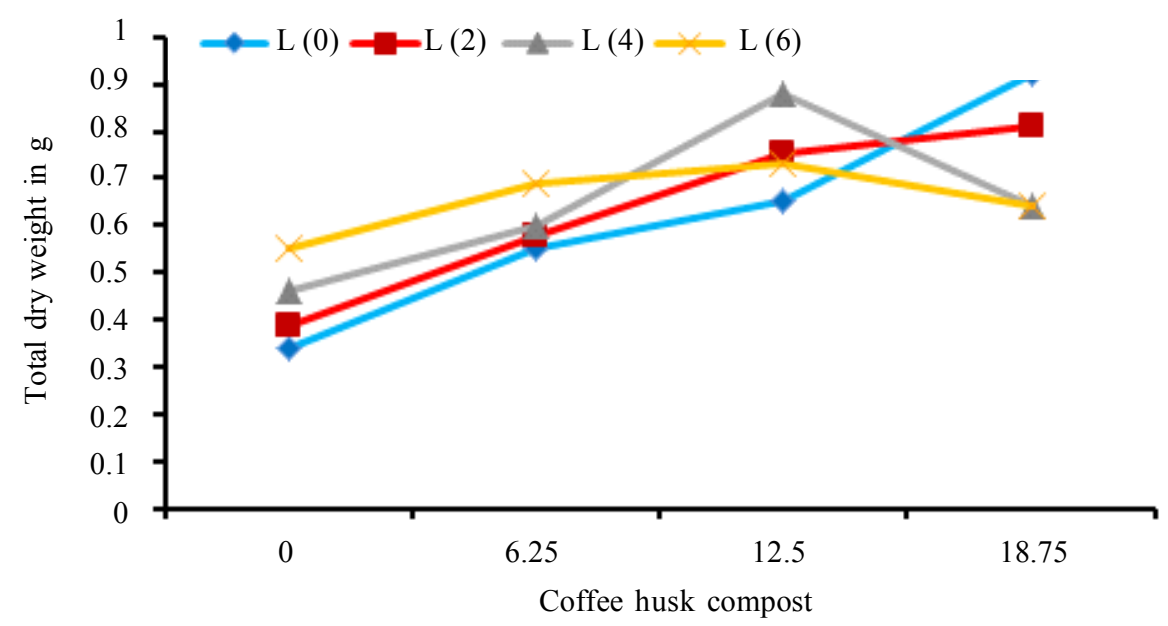

Figure 1. Interaction effects of lime and coffee husk compost $(\mathrm{CHC})$ rates on total dry weight of coffee seedlings 
Table 2. Effect of lime and compost on soil $\mathrm{pH}$, exchangeable acidity, total nitrogen and available phosphorus and potassium

\begin{tabular}{|c|c|c|c|c|c|}
\hline \multirow{2}{*}{ Treatment description } & \multicolumn{4}{|c|}{ Parameters } & \multirow[b]{2}{*}{$\mathrm{K}\left(\right.$ meq $\left.100 \mathrm{~g}^{-1}\right)$} \\
\hline & $\mathrm{pH}\left(\mathrm{H}_{2} \mathrm{O}\right)$ & Ex.A(meq $100 g^{-1}$ ) & TN $(\%)$ & Av. P(ppm) & \\
\hline Control & $4.71^{\mathrm{h}}$ & $3.3^{\mathrm{a}}$ & $0.163^{\mathrm{g}}$ & $8.59^{\mathrm{h}}$ & $0.49^{\mathrm{h}}$ \\
\hline 1.6 t.ha ${ }^{-1} \mathrm{~L}$ & $5.31^{\mathrm{g}}$ & $1.63^{\mathrm{b}}$ & $0.180^{\mathrm{f}}$ & $10.36^{\mathrm{gh}}$ & $0.53^{h}$ \\
\hline 3.2 t.ha ${ }^{-1} \mathrm{~L}$ & $5.61 \mathrm{def}$ & $0.79^{\mathrm{c}}$ & $0.193^{\text {ef }}$ & $14.06^{\mathrm{fg}}$ & $0.57^{\mathrm{h}}$ \\
\hline 4.8 t.ha $^{-1} \mathrm{~L}$ & $5.75^{\text {bcd }}$ & $0.47^{\mathrm{d}}$ & $0.193^{\text {ef }}$ & $16.40^{\mathrm{f}}$ & $0.77^{\mathrm{gh}}$ \\
\hline 5 t.ha $^{-1} \mathrm{C}$ & $5.34^{\mathrm{g}}$ & $1.62^{b}$ & $0.203^{\mathrm{de}}$ & $21.86^{\mathrm{e}}$ & $1.09^{\mathrm{ef}}$ \\
\hline 1.6 t.ha ${ }^{-1} \mathrm{~L}+5$ t.ha $^{-1} \mathrm{C}$ & $5.49^{\mathrm{f}}$ & $0.88^{\mathrm{c}}$ & $0.217^{\mathrm{cde}}$ & $28.83^{\mathrm{d}}$ & $1.04^{\mathrm{fg}}$ \\
\hline 3.2 t.ha ${ }^{-1} \mathrm{~L}+5$ t.ha ${ }^{-1} \mathrm{C}$ & $5.65^{\text {cde }}$ & $0.42^{\mathrm{d}}$ & $0.203^{\mathrm{de}}$ & $29.40^{d}$ & $0.99^{\mathrm{fg}}$ \\
\hline 4.8 t.ha ${ }^{-1} \mathrm{~L}+5$ t.ha ${ }^{-1} \mathrm{C}$ & $5.77^{\mathrm{abcd}}$ & $0.21^{\mathrm{def}}$ & $0.207^{\mathrm{cde}}$ & $29.20^{\mathrm{d}}$ & $0.97 \mathrm{fg}$ \\
\hline 10 t.ha ${ }^{-1} \mathrm{C}$ & $5.59^{\text {ef }}$ & $0.38^{\mathrm{de}}$ & $0.203^{\mathrm{de}}$ & $34.23^{\mathrm{c}}$ & $1.70^{\mathrm{b}}$ \\
\hline 1.6 t.ha ${ }^{-1} \mathrm{~L}+10$ t.ha ${ }^{-1} \mathrm{C}$ & $5.78^{a b c}$ & $0.27^{\mathrm{def}}$ & $0.210^{\text {cde }}$ & $36.09^{\mathrm{c}}$ & $1.45^{\text {bed }}$ \\
\hline 3.2 t.ha ${ }^{-1} \mathrm{~L}+10$ t.ha $^{-1} \mathrm{C}$ & $5.79^{a b c}$ & $0.13^{\text {ef }}$ & $0.223^{b c}$ & $48.31^{\mathrm{a}}$ & $1.38^{\mathrm{cde}}$ \\
\hline 4.8 t.ha ${ }^{-1} \mathrm{~L}+10$ t.ha $^{-1} \mathrm{C}$ & $5.81^{\mathrm{abc}}$ & $0.11^{\mathrm{ef}}$ & $0.223^{\mathrm{bc}}$ & $41.17^{b}$ & $1.24 \mathrm{def}$ \\
\hline 15 t.ha $^{-1} \mathrm{C}$ & $5.75^{\text {bed }}$ & $0.12^{\text {ef }}$ & $0.243^{\mathrm{a}}$ & $51.24^{\mathrm{a}}$ & $2.39^{\mathrm{a}}$ \\
\hline 1.6 t.ha ${ }^{-1} \mathrm{~L}+15$ t.ha ${ }^{-1} \mathrm{C}$ & $5.87^{\mathrm{ab}}$ & $0.10^{\mathrm{f}}$ & $0.237^{\mathrm{ab}}$ & $48.11^{\mathrm{a}}$ & $1.70^{\mathrm{b}}$ \\
\hline 3.2 t.ha $^{-1} \mathrm{~L}+15$ t.ha $^{-1} \mathrm{C}$ & $5.89^{\mathrm{ab}}$ & $0.09^{\mathrm{f}}$ & $0.220^{\text {bcd }}$ & $49.24^{\mathrm{a}}$ & $1.63^{\mathrm{bc}}$ \\
\hline 4.8 t.ha $^{-1} \mathrm{~L}+15$ t.ha $^{-1} \mathrm{C}$ & $5.92^{\mathrm{a}}$ & $0.09^{\mathrm{f}}$ & $0.210^{\text {cde }}$ & $49.80^{\mathrm{a}}$ & $1.75^{\mathrm{b}}$ \\
\hline $\operatorname{DMRT}(5 \%)$ & $* *$ & $* *$ & $*$ & $* *$ & $* *$ \\
\hline CV $(\%)$ & 1.51 & 24.9 & 4.61 & 7.5 & 13.23 \\
\hline
\end{tabular}

yield. Also lime application on the highest compost rate $\left(15\right.$ t.ha $\left.^{-1}\right)$ did not increase the total dry matter. This shows that the potential of the use compost to ameliorate soil acidity without lime as mentioned in the literatures (Kasongo et al., 2013; Nduka et al., 2015). As well as the reduction in total dry matter yield at increased rate of their combination attributed to a reduction in the solubility and availability of $P$ to crops which might be caused by the formation of insoluble Ca-P compounds in the soil (Fageria \& Baligar, 2008), to induced $\mathrm{Fe}, \mathrm{Mn}, \mathrm{Zn}$ and $\mathrm{B}$ deficiency (Fageria, 2009), to high level of Al in plant tissue (Fageria \& Baliger, 2008) and increased cation retention capacity of soil colloids and hence decreased availability of $\mathrm{K}$ and $\mathrm{Mg}$ (Fageria \& Baligar, 2003). All these findings invariably illustrated that, depending on the type of crop species, lime rates which only raise the $\mathrm{pH}$ to levels that neutralize exchangeable $\mathrm{Al}$ or reduced it to lower levels increase crop growth and yield.

\section{Nutrient Uptakes}

\section{Nitrogen}

Compared to the control, application of lime and compost increased nitrogen uptake of the leaf (Table 3). Application of lime alone increased leaf $\mathrm{N}$ - uptake from the control with increasing rate. Correspondingly, nitrogen uptake of the leaf increased by application of compost as compared to the control. The highest $\mathrm{N}$-uptake (16.46 $\mathrm{mg} \mathrm{plant}^{-1}$ ) was obtained from sole application of compost at the rate of 15 t.ha $^{-1}\left(18.75\right.$ g.pot $\left.{ }^{-1}\right)$ and followed by (15.48 mg.plant $\left.\mathrm{t}^{-1}\right)$ which was obtained by combined application of lime (3.2 t.ha $\left.\mathrm{t}^{-1}\right)$ and compost $\left(10\right.$ t.ha $\left.^{-1}\right)$ while, the lowest $\left(1.94 \mathrm{mg}^{\mathrm{p}}\right.$ plant $\left.^{-1}\right)$ was obtained from the control (Table 3 ).

\section{Phosphorus}

Application of lime alone at the respective rates increased P-uptake of coffee seedling leaf as compared to the control plot (Table 3). 
This might be due to increased soil $\mathrm{pH}$ as a result of lime application (Table 2), which enhances the release of phosphate ions fixed by $\mathrm{Al}$ and $\mathrm{Fe}$ ions into the soil solution and increased the absorption of $\mathrm{P}$ by coffee seedling compared to the control. Similarly, application of compost alone increased P-uptake of coffee seedling leaf treated with the respective levels as compared to control (Table 1). Similar to N-uptake the highest P-uptake (5.79 mg.plant $\mathrm{m}^{-1}$ ) was obtained from sole application of compost at the rate of 15 thha $^{-1}$ followed by (5.43 mg.plant $\left.{ }^{-1}\right)$ which was obtained from combined application of lime (3.2 t.ha $\left.{ }^{-1}\right)$ and compost $\left(10\right.$ t.ha $\left.^{-1}\right)$ while, the lowest $\left(0.73 \mathrm{mg}\right.$.plant $\left.{ }^{-1}\right)$ was obtained from the control (Table 3). The increase in leaf nutrient uptake because of compost amendment is likely due to the acid neutralizing capacity of coffee husk compost in addition to its capacity to supply soil nutrients $(\mathrm{N}, \mathrm{P}$, and $\mathrm{K})$. An improved $\mathrm{N}, \mathrm{P}$, and $\mathrm{K}$ uptake by coffee seedlings amended with organic sources such as decomposed coffee husk and farm yard manure also reported by Taye (1998).

\section{Potassium}

Application of lime and compost increased K-uptake of coffee seedlings leaf as compared to the control plot similar to $\mathrm{N}$ and P-uptake (Table 2). Accordingly, leaf $\mathrm{K}$-uptake of coffee seedling was increased by sole application of lime and compost with their respective rates (Table 3). Also the combined effect of lime and compost increased leaf K-uptake.

Similar to leaf N and P-uptake of coffee seedling the highest K-uptake (5.86 mg.plant ${ }^{-1}$ ) of the leaf also obtained from sole application of compost at the rate of 15 tha $^{-1}$ followed by (5.22 mg.plant $\left.{ }^{-1}\right)$ which was obtained from combined application of lime (3.2 t.ha' $\left.{ }^{-1}\right)$ and compost (10 t.ha $\left.{ }^{-1}\right)$ while, the lowest (0.97 mg.plant ${ }^{-1}$ ) was obtained from the control plot (Table 3). The increased N, P, and K uptakes by lime, compost and the combined applications are likely associated to the overall coffee seedlings growth improvement due to soil acidity neutralizing effect of lime and compost to create favorable soil conditions (Table 1). In acidic soils, suppressed and abnormal root morphology due to $\mathrm{Al}$ toxicity (Cyamweshi et al., 2014), directly hinders nutrient uptake as well as water absorption. However, with the application of lime and organic amendments crop nutrient uptake and yield increases significantly (Gitari, 2013).

Compost application increased the absorption of the macronutrients $\mathrm{N}, \mathrm{P}$, and $\mathrm{K}$ compared with the control. For all treatments, coffee seedling from the compost amended plot took up more $\mathrm{N}, \mathrm{P}$, and $\mathrm{K}$ than control and sole lime amended plot, confirming that coffee husk compost is a source of NPK (Table 1). Therefore, the improved nutrient uptake of coffee seedlings through the use of lime and compost amendment particularly coffee husk compost provides alternative fertilizer options and liming materials to farmers as a means of promoting coffee growth on acidic soils. On the other hand, the combination effect of lime and coffee husk compost at the highest rate reduced the nutrient uptake of the coffee seedlings (Table 3). This could be due to high $\mathrm{Ca}$ content in the soil which reduces the availability of another nutrients (Fageria \& Baligar, 2008) as result of the highest rate of lime and coffee husk compost combination. This is because the availability of the nutrients for crop uptake is not only driven by the absolute contents but also by the relative contents whereby relative excess of one element induces relative shortage of another (Eyasu, 2016). 
Table 3. Leaf nutrient uptake (NPK) of coffee seedling as affected by lime and compost amended acidic soil

\begin{tabular}{|c|c|c|c|}
\hline Treatment description & Nitrogen uptake (mg.plant ${ }^{-1}$ ) & Phosphorus uptake (mg.plant ${ }^{-1}$ ) & Potassium uptake (mg.plant ${ }^{-1}$ ) \\
\hline Control & $1.95^{\mathrm{k}}$ & $0.73^{\mathrm{h}}$ & $0.97^{\mathrm{i}}$ \\
\hline 1.6 t.ha- ${ }^{-1} \mathrm{~L}$ & $2.77^{\mathrm{j}}$ & $1.06^{\mathrm{h}}$ & $1.29^{\mathrm{h}}$ \\
\hline 3.2 t.ha ${ }^{-1} \mathrm{~L}$ & $3.59^{\mathrm{i}}$ & $1.44^{\mathrm{g}}$ & $1.61^{\mathrm{h}}$ \\
\hline 4.8 t.ha $^{-1} \mathrm{~L}$ & $5.09^{\mathrm{h}}$ & $1.93^{\mathrm{f}}$ & $2.16^{\mathrm{g}}$ \\
\hline 5 t.ha $^{-1} \mathrm{C}$ & $5.56^{\mathrm{gh}}$ & $2.13^{\mathrm{f}}$ & $2.34^{\mathrm{fg}}$ \\
\hline 1.6 t.ha ${ }^{-1} \mathrm{~L}+5$ t.ha $^{-1} \mathrm{C}$ & $5.90^{\mathrm{g}}$ & $2.26^{\mathrm{f}}$ & $2.37^{\mathrm{fg}}$ \\
\hline 3.2 t.ha ${ }^{-1} \mathrm{~L}+5$ t.ha $^{-1} \mathrm{C}$ & $8.39^{f}$ & $2.74^{\mathrm{e}}$ & $2.52^{\mathrm{f}}$ \\
\hline 4.8 t.ha ${ }^{-1} \mathrm{~L}+5$ t.ha ${ }^{-1} \mathrm{C}$ & $9.75^{\mathrm{e}}$ & $2.98^{\mathrm{e}}$ & $2.97^{\mathrm{e}}$ \\
\hline 10 t.ha $^{-1} \mathrm{C}$ & $8.49^{\mathrm{f}}$ & $2.74^{\mathrm{e}}$ & $2.95^{\mathrm{e}}$ \\
\hline 1.6 t.ha ${ }^{-1} \mathrm{~L}+10$ t.ha ${ }^{-1} \mathrm{C}$ & $11.23^{\mathrm{d}}$ & $3.56^{\mathrm{d}}$ & $3.76^{\mathrm{d}}$ \\
\hline 3.2 t.ha $^{-1} \mathrm{~L}+10$ t.ha $^{-1} \mathrm{C}$ & $15.74^{\text {a }}$ & $5.89^{\mathrm{a}}$ & $5.73^{\mathrm{a}}$ \\
\hline 4.8 t.ha ${ }^{-1} \mathrm{~L}+10$ t.ha $^{-1} \mathrm{C}$ & $12.78^{\mathrm{c}}$ & $4.86^{\mathrm{c}}$ & $4.31^{\mathrm{c}}$ \\
\hline 15 t.ha $^{-1} \mathrm{C}$ & $15.96^{\mathrm{a}}$ & $5.79^{\mathrm{a}}$ & $5.86^{\mathrm{a}}$ \\
\hline 1.6 t.ha ${ }^{-1} \mathrm{~L}+15$ t.ha $^{-1} \mathrm{C}$ & $14.21^{\mathrm{b}}$ & $4.85^{b}$ & $4.86^{\mathrm{b}}$ \\
\hline 3.2 t.ha ${ }^{-1} \mathrm{~L}+15$ t.ha $^{-1} \mathrm{C}$ & $9.16^{\mathrm{e}}$ & $3.42^{\mathrm{d}}$ & $4.16^{\mathrm{c}}$ \\
\hline 4.8 t.ha $^{-1} \mathrm{~L}+15$ t.ha ${ }^{-1} \mathrm{C}$ & $7.91^{\mathrm{f}}$ & $2.93^{\mathrm{e}}$ & $3.83^{\mathrm{d}}$ \\
\hline $\operatorname{DMRT}(5 \%)$ & $* *$ & $* *$ & $* *$ \\
\hline $\mathrm{CV}(\%)$ & 4.39 & 6.97 & 6.17 \\
\hline
\end{tabular}

\section{CONCLUSIONS}

Coffee (Coffea arabica L.) seedling nutrient (NPK) uptake and dry matter yield increased progressively with increase in coffee husk compost rates. Vigorous coffee seedlings with high dry matter yield and nutrient (NPK) uptake were obtained by combined application of coffee husk compost and lime at the rate of $10 \mathrm{t} \mathrm{ha}^{-1}$ and $3.2 \mathrm{t}^{\mathrm{h}} \mathrm{ha}^{-1}$, respectively. However, the growth of coffee seedlings at the highest rate of their combination (lime and coffee husk compost) were retarded. Therefore, this study showed that a promising potential of coffee husk compost amendment alone or in combination with conventional lime to ameliorate soil acidity and improve nutrient availability for coffee seedling growth.

\section{ACKNOWLEDGEMENTS}

The author gratefully acknowledge The Ethiopian Institute of Agricultural Research for the financial support of the study.

\section{REFERENCES}

Abayneh, M. \& F. Ittana (2015). Nutritional requirement and management of Arabica coffee (Coffea arabica L.) in Ethiopia: National and global perspectives. American Journal of Experimental Agriculture, 5(5), 400-418.

Ahmad R.; A. Naseer; Z.A. Zahir; M. Arshad; T. Sultan \& M.A. Ullah (2006). Integrated use of recycled organic waste and chemical fertilizers for improving maize yield. International Jurnal of Agriculture and Biology, 8(6), 840-843.

Ano, A.O. \& C.I. Ubochi (2007). Neutralization of soil acidity by animal manure: Mechanism of reaction. African Journal of Biotechnology, 6 (4), 364-368.

Barecha, G.; F. Lamessa \& M. Wakjira (2011). Exploring the suitability of coffee pulp compost as growth media substitute in greenhouse production. International Journal of Agricultural Research, 6(3), 255-267.

Bekeko, Z. (2013). Effect of maize stover application as soil mulch on yield of Arabica coffee (Coffea arabica L., Rubiaceae) 
at Western HarargheZone, Eastern Ethiopia. Sustainable Agriculture Research, 2, 15-21.

Chemura, A. (2014). The growth response of coffee (Coffea arabica L.) plants to organic manure, inorganic fertilizers and integrated soil fertility management under different irrigation water supply levels. International Journal of Recycle Organic Waste in Agriculture, 3(59), 1-9.

CSA (2016). Report on Area and Production of Major Crops. Private Peasant Holdings, 2016/17 Meher Season. Volume 1. Central Stastical Agency, Ethiopia.

Cyamweshi, R.A.; N.L. Nabahungu; A. Mukashema; V. Ruganzu; M.C. Gatarayiha; A. Nduwumuremyi \& J.J. Mbonigaba (2014). Enhancing nutrient availability and coffee yield on acid soils of the central plateau of southern Rwanda. Global Journal of Agricultural Research, 2(2), 44-55.

Dubale, P. (1994). Ecology and soils of major coffee growing regions of Ethiopia. In: Mineral Fertilization of Coffee in Ethiopia (Paulos Dubale, Ed.). Institute of Agricultural Research (IAR), Addis Ababa, Ethiopia.

Dzung, N.A.; T.T. Dzung \& V.T.P. Khanh (2013). Evaluation of compost for improving soil fertility and sustainable coffee production in rural central highland of Vietnam. Resources and Environment, 3(4), 77-82.

Edjamo, Y.; T. Shimber; A. Yilma; A. Netsere; T. Negewo; M. Abachebsa \& B. Bogale (1996). Advances in coffee agronomy research in Ethiopia. p. 40-45. In: Proceedings of Inter Africa Coffee Organization (IACO) Workshop, 4-6 September 1995, Kampala, Uganda.

EIAR (2015). Crop Research Technology Recommendations. Ethiopian Institute of Agricultural Research Addis Ababa, Ethiopia.

Elias, E. (2016). Soil of Ethiopian Highlands: Geomorphology and Properties.
CASCAPE Project, ALTERA, Wageningen University and Research Centre (Wageningen UR). The Netherlands.

Endris, S. (2006). Accelerated composting of coffee processing by products: An organic option for soil fertility management in the coffee based cropping system of south western Ethiopia. p. 1084-1089. In: Proceeding of $21^{\text {st }}$ International scientific conference on coffee science $(A S I C)$, Montpelier, France, .

Endris, S.; T. Kebede; T. Yaekob; Y. Kassahun \& J. Dawid (2008). The challenges and opportunities of organic fertilizers in coffee. p. 226-233. In: Coffee Diversity and Knowledge (G. Adugna; B. Belachew; T. Shimber; E. Taye \& T. Kufa. Eds.). Proceedings of National Workshop Four Decades of Coffee Research and Development in Ethiopia, 14-17 August 2007, Addis Ababa, Ethiopia.

Fageria, N.K. (2009). The Use of Nutrients in Crop Plants. CRC Press, New York.

Fageria, N.K. \& V.C. Baligar (2003). Fertility management of tropical acid soils for sustainable crop production. p. 359385. In: Hand Book of Soil Acidity (Z. Rengel, Ed.). University of Western Australia, Perth, Western Australia, Australia.

Fageria, N.K. \& V.C. Baligar (2008). Ameliorating soil acidity of tropical oxisols by liming for sustainable crop production. Advance in Agronomy, 99, 345-400.

Gitari, H.I. (2013). Lime and Manure Application to Acid Soils and their Effects on Bio-Chemical Soil Properties and Maize Performance at Kavutiri-Embu County. Doctoral Dissertation, Kenyatta University.

Gray, Q.; A. Tefera \& T. Tefera (2013). Ethiopia: Coffee Annual Report. GAIN Report No. ET-1302, GAIN Report Assessment of Commodity and Trade by USDA, USA.

IAR (1996). Recommended Production Technologies for Coffee and Associated Crops. 
Institute of Agricultural Research. Addis Ababa, Ethiopia.

Ibiremo, O.S. \& O.S.O. Akanbi (2016). Soil properties and nutrient uptake of coffee seedlings as influenced by NPK fertilizer formulations in Ibadan, Southwest, Nigeria. British Journal of Applied Science \& Technology, 12(3), 1-8.

Jackson, M.L. (1958). Soil Chemical Analysis. Prentice Hall. Englewood Clifs, N.J.

Kamprath, E.J. (1984). Crop response to lime on soils in the humid tropics. p. 348-368. In: Soil Acidity and Liming. (R.E. Adams, Ed.). American Society of Agronomy, Madison, Wisconsin, USA.

Kasongo R.K.; A. Verdoodt; P. Kanyankagote; G. Baert \& E. Van Ranst (2011). Coffee waste as an alternative fertilizer with soil improving properties for sandy soils in humid tropical environments. Soil Use and Management, 27, 94-102

Kasongo, R.K.; A. Verdoodt; P. Kanyankogote; G. Baert \& E. Van Ranst (2013). Response of Italian ryegrass (Lolium multiflorum Lam.) to coffee waste application on a humid tropical sandy soil. Soil Use and Management, 29, 22-29.

Kassa, H. \& T. Workayehu (2014). Evaluation of some additives on coffee residue (coffee husk and pulp) quality as compost, southern Ethiopia. International Invention Journal of Agricultural and Soil Science, 2(2), 14-21.

Kufa, T. (1998). Response of Arabica Coffee (Coffea arabica L.) to Various Soil Fertility Management. Master of Science Thesis. Haramaya University. Haramaya, Ethiopia.
Mikru, Z. \& W. Tena (2008). Potentials and constraints of Nitisols and Acrisols. p. 209-216. In: Coffee Diversity and Knowledge (G. Adugna; B. Belachew; T. Shimber; E. Taye \& T. Kufa, Eds.). Proceedings of National Workshop Four Decades of Coffee Research and Development in Ethiopia, 14-17 August 2007, Addis Ababa, Ethiopia.

Nduka, B.A.; D.B. Adewale; O.S.O. Akanbi \& K.B. Adejobi (2015). Nursery soil amendments for cashew seedling production : A comparative analysis of coffee husk and NPK. Journal of Agricultural Science, 7(3), 111-122.

Netsere, A. (2015). Response of coffee (Coffea arabica L.) seedlings to lime and phosphorus mineral fertilizer at Jimma, Southwestern Ethiopia. Journal of Biology, Agriculture and Healthcare, 5(13), 27-32.

Netsere, A.; T. Kufa \& T. Shimber (2015). Review of Arabica coffee management research in Ethiopia. Journal of Biology, Agriculture and Healthcare, 5(13), 235-258.

Patricia, F. (2011). The Coffee Exporter's Guide. $3^{\text {rd }}$ eds., International Trade Centre, Geneva.

SAS Institute Inc. (2011) SAS ${ }^{\circledR} 9.3$ Macro Language: Reference. SAS Institute Inc., Cary, N.C.

Takala, B.; T. Kufa \& A. Regassa (2020). Effects of lime and coffee husk compost on growth of coffee seedlings on acidic soil of Haru in Western Ethiopia. Journal of Degraded and Mining Land Management, 8(1), 2391-2400.

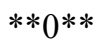

